\title{
Role and efficacy of music therapy in learning disability: a systematic review
}

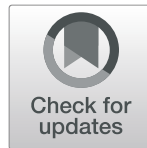

Feeby Mina ${ }^{1 *}$ D, Mohammed El Sayed Darweesh ${ }^{1}$, Ahmed Nabil Khattab² and Shaimaa Mohammed Serag ${ }^{1}$

\begin{abstract}
Background: Kids with learning disabilities can succeed in school and improve their educational level with the help of a correct rehabilitation program; one of the most effective rehabilitation programs is music therapy. As there was little proof educating us knowledge regarding the function of music treatment in the improvement of learning incapacitated kids in this way, it was imperative to gather these bits of studies in a systematic review study to feature the role of music treatment in the restoration of learning disabilities.

The aim of this work is to study the relation between music therapy and learning disabilities, to define the music therapy role and efficacy in the enhancement of learning disabled children to be able to delineate an efficient program therapy later on.

This study is a systematic review and was carried out according to the guidelines of the Preferred Reporting Items for Systematic Reviews and Meta-Analyses (PRISMA) protocol.

Main text: The reviewed included studies were intervention studies that used different groups of cases (learning disabled, dyslexic, or with mathematical problems children) which received the music therapy versus different control groups (normal or dyslexic) receiving normal reading program, cognitive or placebo therapy; also they applied different methods and programs of music therapy. Most of the included studies reported that music therapy is a useful aiding factor in rehabilitation therapy of reading and phonological awareness disorders, however little evidence for positive effectiveness regarding spelling, arithmetic, writing, cognitive abilities, working memory, auditory attention, and rapid auditory processing.

Conclusion: Music therapy (with or without cognitive therapy) has an important and augmenting role in improving reading skills and phonological awareness problems in dyslexic children but does not replace the current methods of rehabilitation. There is little evidence found that music therapy (with or without cognitive therapy) is an effective aiding factor in rehabilitation therapy regarding spelling, arithmetic, writing, cognitive abilities, working memory, auditory attention, and rapid auditory processing in learning disabled children.
\end{abstract}

Keywords: Music therapy, Learning disability

\footnotetext{
* Correspondence: feebymina1@gmail.com

${ }^{1}$ Unit of Phoniatrics, Otorhinolaryngology Department, Faculty of Medicine,

Tanta University, Tanta, Egypt

Full list of author information is available at the end of the article
}

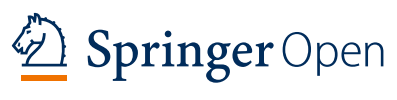

(c) The Author(s). 2021 Open Access This article is licensed under a Creative Commons Attribution 4.0 International License, which permits use, sharing, adaptation, distribution and reproduction in any medium or format, as long as you give appropriate credit to the original author(s) and the source, provide a link to the Creative Commons licence, and indicate if changes were made. The images or other third party material in this article are included in the article's Creative Commons licence, unless indicated otherwise in a credit line to the material. If material is not included in the article's Creative Commons licence and your intended use is not permitted by statutory regulation or exceeds the permitted use, you will need to obtain permission directly from the copyright holder. To view a copy of this licence, visit http://creativecommons.org/licenses/by/4.0/. 


\section{Background}

Learning disability is a conventional term which related to a heterogeneous gathering of issues described by significant problems in acquisition and use of listening, talking, reading (dyslexia), writing (dysgraphia), or numerical capacities (dyscalculia), despite average IQ, ordinary scholarly, auditory, and visual capacities, appropriate motivation, and satisfactory socio-cultural chance. They can also interfere with higher-level skills, for example, organization, time planning, and dynamic thinking [1].

Dyslexia, which is characterized as a specific reading difficulty, has been the subject of studies with results showing functional and structural brain abnormalities from both genetic and cultural origins. A few hypotheses show that language and education issues experienced by dyslexics are brought about by deficits derive from abnormal neurological timing or "temporal processing" [2].

One of the methods of restoration of these abilities is music therapy. Music therapy is an established health profession in which music is used within a therapeutic relationship to address the physical, communicative, emotional, cognitive, and behavioral needs of people [3].

Music therapy has been demonstrated to be useful in language, speech, auditory, and learning recovery for cases with learning disabilities [4].

It is generally accepted that music learning, music perusing, or potentially music investment upgrade scholastic achievement, particularly reading in many ways. One of these ways is that music training influences auditory aptitudes related to both music and language. For instance, music preparation has appeared to accelerate the advancement of harmony perception in 4-and5-year-olds, as well as make quicker development in brain reactions to stimuli. Moreover, it was found that dyslexics show that difficulties are impeded at quick temporal processing, pitch, and rhythm abilities, and all of which are improved by music training. In another way, learning to read melodic documentation includes huge numbers of similar processes as learning how to decode words, for example, understanding that composed documentation continues from left to right, perceiving visual examples, and understanding that visual images map on to specific sounds [5].

Furthermore, singing may help reading improvement, as it includes reading unsurprising content, dividing words into syllables. In addition to that, the relationship between music exercises, general IQ, and arithmetic abilities has been viewed as the best case of far exchange coming about because of music training [6].

It has additionally been proposed that music learning shows youngsters inspirational and fixation aptitudes that assist them with attention for significant stretches of time, along these lines, possibly helping them to continue on at acquiring reading [7].
Finally, it is conceivable that music training at first improves phonological awareness abilities, particularly in small kids who are simply starting to read, though the impacts of longer training reach out to word decoding abilities, particularly in youngsters who are getting more familiar with reading [8].

There are different procedures of music therapy in learning disabilities. For maintaining attention, Nicholson [9] used body movements taught contrasting concepts such as high-low, loud-soft, and fast-slow using music sound and singing and connected letters of the alphabet to musical pitches by playing the xylophone while reading notation.

For enhanced neurological development and better preparation of the young child for academic tasks, music educators as Orff, Dalcroze, and Kodály each professed idiosyncratic music instruction deemed the most important; they had in common the belief that the brain learns through multisensory instruction and is ready to do so at an early age. They described specific music activities in a developmental model that allowed children to begin successfully participating at an early age and performing "quality" music that is conforming to a classical Western music sound [10].

For stimulation of auditory attention and perception and working memory abilities Habib [11], in 2016, designed Cognitive-Musical Training (CMT). The program comprises a battery of musical tasks and exercises based on these components and on the active listening to various sorts of musical stimuli. Multimodal training combining different modalities, as is typically the case in real life, was achieved through tasks that simultaneously involve visual, auditory, and sensory-motor processing. Simplified visual and gestural supports were provided that were adapted to each child's level of performance. For instance, a very simple musical notation system was purposefully devised, made of only 3 or 5 strokes to represent the pitch and duration of sounds.

As minimal information tells us about the use of music therapy in learning disabilities, so research is required to highlight the efficacy of music therapy in learning disabilities.

\section{Methods}

The systematic review was carried out according to the guidelines of the PRISMA protocol for systematic reviews.

\section{Search methods for identification of studies Eligibility criteria (criteria for considering studies for this systematic review)}

Study design We included prospective intervention studies; whether randomized or not, controlled or not, 
focusing on the effects of music therapy in learning disabled children. We excluded other types of study designs.

Study participants We included studies on learning disabled children aged from 5 to 12 years old, with average intelligence quotient according to the IQ test. Children must be assessed and diagnosed as learning disabled by any standardized or unstandardized tests and/or batteries.

Intervention Any approach of music therapy alone or combined with cognitive therapy compared with a control group. Music therapy can be in the form: individual or group music lessons or musical training with a music advisor or teacher at music school (extracurricular) or at the school where the children are receiving their formal instruction, either as part of the general curriculum or as additional tuition. Children may be encouraged to sing songs (like the alphabet and letter recognition songs), use body movements that teach contrasting concepts, learn musical notation system to represent pitch and duration of sounds, for the rhythmic aspect, or may be exposed to a specific musical methodological approach (e.g., Dalcroze Method, Kodaly Method, Suzuki Method or Orff Approach).

Outcomes We included studies that reported the impact of music therapy on the following planned outcomes: reading skills, reading fluency, phonological awareness, spelling, writing skills, or arithmetic cognition, any, or some, or all.

Language Included studies must be in English.

Place Included studies must be conducted at governmental or nongovernmental schools, hospitals, or institutes.

Publication We included studies published in a peerreviewed journal, in the duration (from 1st January 1999 to 30th October 2020).

\section{Search strategy and search terms}

We ran the electronic searches in April 2020 and updated them in November 2020. To identify relevant studies, we systematically searched the following databases: PubMed and Science Direct for intervention studies focusing on the effects of music therapy in learning disabled children through using the search terms (Learning disability/Dyslexia/Reading disability/Dysgraphia/ Writing problems/Dyscalculia/Arithmetic problems with music/music therapy/music training). We developed an advanced search strategy through the following search filters: (type of search terms, language, type of study, publication date) on PubMed and Science Direct. We saved our research results on a created collection on these databases and adapted them for notifying with updates. Following that, all results were exported into one sheet then exact duplicates were identified and excluded.

\section{Selection of studies}

Two reviewer authors independently scanned the titles and abstracts of articles identified from electronic searches. The initial selection was wide-ranging to ensure that as many studies as possible are assessed as to their significance to the systematic review. The irrelevant articles were excluded in the early stages of the search (e.g., on the basis of titles presented in electronic searches) while those eligible articles, from their title or abstract, were obtained in full text and underwent further reading based on the eligibility criteria.

\section{Data collection and analysis}

For each included study, two review authors independently extracted data of authors, publication year, country, study design, sample size, ages, intervention, and outcomes. Any disagreements were resolved through discussions.

\section{Bias risk among the included studies}

Two review authors independently assessed the methodological quality using the Cochrane Risk of Bias Assessment Tool. We created a risk of bias table and included a description and a judgment (low risk of bias, high risk of bias, or unclear risk of bias) for each of the included studies. "Low risk of bias" was given to the articles who were thoroughly discussing their article concerning the specific bias. "Unclear risk of bias" was given to those who were not specifically stating how the bias affected their results, but where we, as readers, could evaluate this by interpreting text and data. "High risk of bias" was given to the articles where an evaluation of the bias could not be made sufficiently.

\section{Results}

Our electronic search yielded totally 277 studies (38 collected from Pubmed and 239 collected from Science Direct), then 84 duplicated studies, which were detected by reference management software and revised by the first author, were removed. After removal of duplicates, the remaining 193 studies were examined by two authors on the base of title and abstract, so 186 studies were excluded (10 studies excluded for having different subjects, 20 studies excluded for having different study designs, 2 studies excluded for being in a different language, 154 studies excluded for being not related to research topics). Finally, 7 studies were undergone full-text 
revision so that they could be included in this systematic review. Figure 1 shows the flow chart of excluded and included studies collected from our search. Note that the references of the 7 included articles in this system are numbered from [11-17].

The 7 included studies came from different countries ( 2 studies from Brazil, 1 study from France, 1 study from Italy, 1 study from Albania, 1 study from the USA, and 1 study from the UK). There were 7 prospective interventional studies (i.e., pre/post-test design); 5 of them had a control group; however, 2 studies did not have, 4 of included studies were randomized but 3 studies were not randomized. The age range was from 6 to 12 years. The sample size ranged from 12 to 235 participants.

Table 1shows the authors' names, the year of publication, the study design, the sample size, the age of participants, the aim of the 7 included studies, and the outcome measures.

All participants of average intelligence, with the diagnosis of dyslexia in 5 studies, learning disability in 1 study, and low arithmetic achievement in 1 study. All included studies performed music intervention program (4 studies applied only music therapy, 3 studies applied combined cognitive therapy and music therapy). All studies performed pre-/post-test comparisons with variant outcome measures.

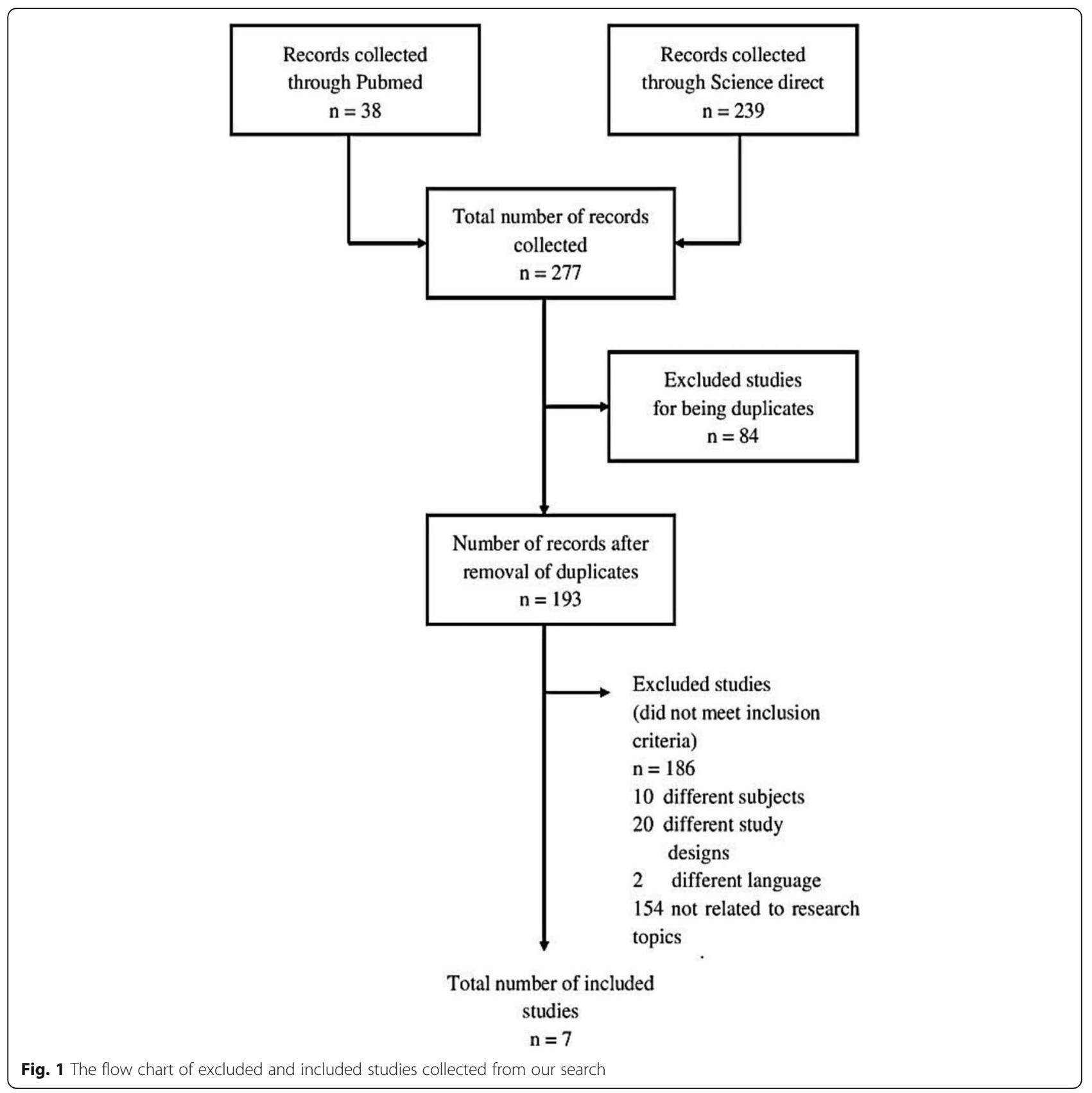


Table 1 Summary of authors' names, year of publication, study design, sample size, age of participants, aim, and outcome measures of included studies

\begin{tabular}{|c|c|c|c|c|c|c|}
\hline $\begin{array}{l}\text { Author(s), } \\
\text { year }\end{array}$ & Country & Study design & Sample size & Age & Aim & Outcome measures \\
\hline $\begin{array}{l}\text { 1. Riberio } \\
\text { and Santos, } \\
2017[12]\end{array}$ & Brazil & $\begin{array}{l}\text { A prospective } \\
\text { interventional trial }\end{array}$ & $\begin{array}{l}\text {-EA (expected } \\
\text { achievement in } \\
\text { math ) } n=26 \\
\text {-LA (low } \\
\text { achievement in } \\
\text { Math) } n=20 \\
\text {-The data of } \\
\text { normative study } \\
\text { functioned as a } \\
\text { control (untrained) } \\
\text { group }\end{array}$ & $\begin{array}{l}\text { Mean } \\
100.09 \\
\pm 3.47 \\
\text { months }\end{array}$ & $\begin{array}{l}\text { Verify the efficacy of a non- } \\
\text { instrumental musical training (NIMT) } \\
\text { in children with low achievement in } \\
\text { math }\end{array}$ & $\begin{array}{l}\text { The Zareki-R test for numerical cognition } \\
\text { pre- and post-NIMT }\end{array}$ \\
\hline $\begin{array}{l}\text { 2. Habib } \\
\text { et al., } 2016 \\
{[11]}\end{array}$ & France & $\begin{array}{l}\text { A prospective } \\
\text { interventional } \\
\text { randomized } \\
\text { controlled trial }\end{array}$ & $\begin{array}{l}\text { Study } 1 \text { and } 2 \\
\text {-Dyslexic group } \\
(N=12) \text {. } \\
\text {-Control group } \\
(N=22) \text {. } \\
\text { (normal readers) }\end{array}$ & $\begin{array}{l}\text { Mean } \\
10.7 \pm \\
17 \\
\text { years }\end{array}$ & $\begin{array}{l}\text { Study the efficacy of the new musical } \\
\text { training method to improve reading } \\
\text { disorders. }\end{array}$ & $\begin{array}{l}\text { The battery of reading and other } \\
\text { psychometric tests pre and post the CMT }\end{array}$ \\
\hline $\begin{array}{l}\text { 3.Flaugnaco } \\
\text { et al., } 2015 \\
{[13]}\end{array}$ & Italy & $\begin{array}{l}\text { A prospective } \\
\text { interventional } \\
\text { randomized } \\
\text { controlled trial }\end{array}$ & $\begin{array}{l}\text {-Music group }(N= \\
24) \text {. } \\
\text {-Control group } \\
(N=22) \text {. } \\
\text {-Total ( } N=26 \\
\text { dyslexic children). }\end{array}$ & $\begin{array}{l}8-11 \\
\text { years }\end{array}$ & $\begin{array}{l}\text { Verify that music training improves } \\
\text { P.A. and reading skills in dyslexic } \\
\text { children through improving temporal } \\
\text { processing and rhythm abilities. }\end{array}$ & $\begin{array}{l}\text {-Italian standardized test for reading } \\
\text { abilities } \\
\text {-Pseudo-words repetition test of Promea } \\
\text { Battery for Phonological awareness } \\
\text {-The BIA Battery for auditory attention }\end{array}$ \\
\hline $\begin{array}{l}\text { 4. Skeja } \\
2014[14]\end{array}$ & Albania & $\begin{array}{l}\text { A prospective } \\
\text { interventional } \\
\text { controlled trial (not } \\
\text { randomized) }\end{array}$ & $\begin{array}{l}\text {-Experimental } \\
\text { group }(N=6) \\
\text {-Control group } \\
(N=6) \\
\text {-Total }(N=12 \\
\text { dyslexic children). }\end{array}$ & $\begin{array}{l}6-7 \\
\text { years }\end{array}$ & $\begin{array}{l}\text { Evaluate the effect of Cognitive } \\
\text { intervention program in association } \\
\text { with music therapy for children with } \\
\text { learning disabilities. }\end{array}$ & $\begin{array}{l}\text { Cognitive Assessment System- CAS pre- } \\
\text { and post-training }\end{array}$ \\
\hline $\begin{array}{l}\text { 5. Cogo- } \\
\text { Moreira } \\
\text { et al., } 2013 \\
\text { [15] }\end{array}$ & Brazil & $\begin{array}{l}\text { A prospective } \\
\text { interventional } \\
\text { pragmatic cluster- } \\
\text { randomized con- } \\
\text { trolled trial }\end{array}$ & $\begin{array}{l}\text {-Intervention } \\
\text { schools }(N=5) \\
\text {-Intervention } \\
\text { music classes ( } N= \\
114) \text {. } \\
\text {-Control schools } \\
(N=5) \\
-C o n t r o l ~ c l a s s e s \\
(N=121) \\
\text {-Total ( } N=235 \\
\text { dyslexic children } \\
\text { from } 10 \text { schools) }\end{array}$ & $\begin{array}{l}8-10 \\
\text { years } \\
\text { Mean } \\
9.15 \pm \\
0.05\end{array}$ & $\begin{array}{l}\text { Evaluate the effectiveness of music } \\
\text { education for the improvement of } \\
\text { reading skills and academic } \\
\text { achievement among dyslexic } \\
\text { children }\end{array}$ & $\begin{array}{l}\text { *The Test of Phonological Awareness } \\
{ }^{*} \text { A word accuracy task } \\
{ }^{*} \text { A non-word accuracy task } \\
{ }^{*} \text { An in-text accuracy task }\end{array}$ \\
\hline $\begin{array}{l}\text { 6. Register } \\
\text { et al., } 2007 \\
{[16]}\end{array}$ & USA & $\begin{array}{l}\text { A prospective } \\
\text { interventional } \\
\text { controlled trial } \\
\text { (Smaller pilot study } \\
\text { on intact } \\
\text { classroom) }\end{array}$ & $\begin{array}{l}\text {-Reading disability } \\
\text { group }(N=8) \text {. } \\
\text {-Treatment class } \\
(N=17) \text {. } \\
\text {-Control class ( } N= \\
\text { 16). } \\
\text { (Heterogeneity of } \\
\text { samples) }\end{array}$ & $\begin{array}{l}7-8 \\
\text { years }\end{array}$ & $\begin{array}{l}\text { Determine the efficacy of music used } \\
\text { as a remedial strategy to enhance } \\
\text { reading skills in } 2 \text { nd-grade students } \\
\text { and Students with (SLD) in reading. }\end{array}$ & $\begin{array}{l}\text { The Gates-MacGinitie Reading Test- } \\
\text { Fourth edition (GMRT) } \\
\text { pre- and post-intervention }\end{array}$ \\
\hline $\begin{array}{l}\text { 7. Overy, } \\
2003[17]\end{array}$ & The UK & $\begin{array}{l}\text {-Study (1): } \\
\text { Observational } \\
\text {-Study (2): } \\
\text { Prospective } \\
\text { interventional (not } \\
\text { controlled) trial } \\
\text {-Study (1): Pretest } \\
\text { control } \\
\text {-Study (2): Control } \\
\text { period equal to } \\
\text { the music } \\
\text { intervention period } \\
\text {-No control group. }\end{array}$ & $\begin{array}{l}\text {-Study (1): } \\
\text { Participating in } \\
\text { music project } \\
\text { group ( } N=28) \text {. } \\
\text { According to } \\
\text { dyslexia screening } \\
\text { test scores } \\
\text { *Strong risk }(N=6) \text {. } \\
\text { *Mild risk }(N=6) \text {. } \\
\text { *No risk }(N=6) \text {. } \\
\text {-Study (2) } \\
\text { Dyslexic group } \\
(N=9) \text {. }\end{array}$ & $\begin{array}{l}\text {-Study } \\
(1) \\
\text { mean } \\
\text { age } 6.7 \\
\text {-Study } \\
(2) \\
\text { mean } \\
\text { age } 8.8\end{array}$ & $\begin{array}{l}\text {-1ry aim: } \\
\text { Evaluate the potential of music } \\
\text { lessons as a support tool for dyslexic } \\
\text { children } \\
\text {-2ry aim: } \\
\text { Explore the specific nature of dyslexic } \\
\text { children's difficulties with musical } \\
\text { timing. }\end{array}$ & $\begin{array}{l}\text { The dyslexia screening test (DST), the } \\
\text { Wechsler Objective Reading Dimensions } \\
\text { (WORD) tests, the Dyslexia Early } \\
\text { Screening Test (DEST), the phonological } \\
\text { abilities test (pat) }\end{array}$ \\
\hline
\end{tabular}


Table 2 shows the criteria of participants, the settings, and the interventional methods of the included studies.

Table 3 shows the results of our included studies, determining the significance of music therapy effect on reading skills, phonological awareness, spelling ability, writing skills, arithmetic skills, cognitive abilities, working memory auditory attention, and rapid auditory processing.
Table 4 shows the reviewer authors' judgments about each risk of bias item for each included study.

\section{Effectiveness of interventions}

Six studies reported positive effectiveness of their interventions and one study [15] reported mixed results and suggested that more investigations and more data are needed.

Table 2 Summary of criteria of participants, settings, and interventional methods of included studies

\begin{tabular}{|c|c|c|c|}
\hline Study & Participants criteria & Setting & Intervention \\
\hline $\begin{array}{l}\text { 1. Riberio } \\
\text { and Santos, } \\
2017[12]\end{array}$ & $\begin{array}{l}\text {-Native Portuguese speakers, not bilingual } \\
\text {-LA group confirmed the diagnosis of low } \\
\text { achievement in Math }\end{array}$ & & $\begin{array}{l}\text {-Giving } 14 \text { sessions of non-instrumental musical } \\
\text { training (NIMT), including } 7 \text { sessions of melodic ac- } \\
\text { tivities\& } 7 \text { sessions of rhythmic activities, each in } 1 \mathrm{~h} \text {, } \\
\text { once/weak, for both LA\& EA groups }\end{array}$ \\
\hline $\begin{array}{l}\text { 2. Habib } \\
\text { et al., } 2016 \\
{[11]}\end{array}$ & $\begin{array}{l}\text {-Dyslexic group with diagnosis of severe dyslexia, } \\
\text { receiving support in specialized classes and } \\
\text { involved in intensive conventional rehabilitation } \\
\text {-Preserved general intelligence }\end{array}$ & $\begin{array}{l}\text {-Study (1): } \\
\text { Outbuilding of the } \\
\text { University Hospital } \\
\text {-Study (2): } \\
\text { Specialized class during } \\
\text { school time }\end{array}$ & $\begin{array}{l}\text {-Study (1): } \\
\text { Giving Cognitive- Musical Training (CMT) sessions, } 6 \\
\text { h/day for } 3 \text { whole days ( } 3 \text { sessions: } \\
\text { 1-musical exercises } \\
\text { 2-musical education } \\
\text { 3-percussion) each in } 45 \text { min then dance activity for } \\
\text { the dyslexic group without reading or writing } \\
\text { rehabilitation } \\
\text {-Study (2): } \\
\text { Giving } 4 \text { interventions ( } 2 \text { workshops of } 1 \text { h of CMT\& } \\
2 \text { musical workshops of } 1 / 2 \text { h), } 3 \text { h/week for } 6 \text { weeks }\end{array}$ \\
\hline $\begin{array}{l}3 . \\
\text { Flaugnacco } \\
\text { et al., } 2015 \\
{[13]}\end{array}$ & $\begin{array}{l}\text {-Native Italian language } \\
\text {-Two dyslexic groups with diagnosis of dyslexia } \\
\text {-Average general intelligence } \\
\text { - Normal hearing, visual, neurological and } \\
\text { psychological examination } \\
\text {-Without specific language or speech } \\
\text { developmental disorders }\end{array}$ & $\begin{array}{l}\text { Local Health Service and } \\
\text { Rehabilitation Center }\end{array}$ & $\begin{array}{l}\text {-Giving music training by percussive instruments, } \\
\text { use of rhythm syllables, rhythmic body } \\
\text { movements\& sensorimotor synchronization games } \\
\text { for the music group } \\
\text {-Training } 2 \text { sessions/week, each in } 1 \mathrm{~h} \text { for } 30 \text { weeks, } \\
\text { in addition to daily conventional rehabilitation of } \\
20 \text { min with parents at home for both groups }\end{array}$ \\
\hline $\begin{array}{l}\text { 4. Skeja, } \\
2014[14]\end{array}$ & $\begin{array}{l}\text { Two dyslexic groups with the diagnosis of } \\
\text { learning disability }\end{array}$ & Daycare center & $\begin{array}{l}\text {-Giving music therapy- Cognitive Intervention } \\
\text { Program to the experimental group, only cognitive } \\
\text { intervention program to control group } \\
\text {-Training of both in } 40 \text { sessions for } 3 \text { months for } \\
\text { each group }\end{array}$ \\
\hline $\begin{array}{l}\text { 5. Cogo- } \\
\text { Moreira } \\
\text { et al., } 2013 \\
{[15]}\end{array}$ & $\begin{array}{l}\text {-All participants diagnosed as poor readers } \\
\text {-Average non-verbal intelligence } \\
\text {-Not receiving any speech or hearing or music } \\
\text { therapy }\end{array}$ & Public schools & $\begin{array}{l}\text {-Training of musical improvisation, composition, } \\
\text { interpretation, creation of own music \& } \\
\text { identification of rhythm, melody and harmony, } \\
\text { given to intervention schools only, no therapy for } \\
\text { control schools } \\
\text {-Giving } 3 \text { sessions/week, each in } 50 \text { min, for } 5 \\
\text { months }\end{array}$ \\
\hline $\begin{array}{l}\text { 6. Register } \\
\text { et al., } 2007 \\
{[16]}\end{array}$ & $\begin{array}{l}\text { Children diagnosed with the specific reading } \\
\text { disability in the reading disability group }\end{array}$ & $\begin{array}{l}\text { Classrooms of } 2 \text { Public } \\
\text { schools }\end{array}$ & $\begin{array}{l}\text {-Teaching } 12 \text { music/reading lessons including word } \\
\text { knowledge, word decoding, reading } \\
\text { comprehension, listening to music, singing, playing } \\
\text { instruments\& movement with music, given to } \\
\text { treatment groups (reading disability group and } \\
\text { treatment class) while giving normal reading } \\
\text { program to control group } \\
\text {-Treatment course of } 3 \text { sessions/week for } 1 \text { month }\end{array}$ \\
\hline $\begin{array}{l}\text { 7. Overy, } \\
2003[17]\end{array}$ & $\begin{array}{l}\text {-Study (1): } \\
\text { Children participating in the music project } \\
\text { screened for dyslexia } \\
\text {-Study (2): } \\
\text { Children (boys) with a diagnosis of dyslexia }\end{array}$ & $\begin{array}{l}\text { - Study (1): } \\
\text { Classroom of school } \\
\text { participating in a music } \\
\text { project } \\
\text {-Study (2): } \\
\text { Classroom of the school } \\
\text { offering a high level of } \\
\text { literacy and regular music } \\
\text { lessons }\end{array}$ & $\begin{array}{l}\text { - Study (1): } \\
\text { In the music project, training sessions of } 20 \text { min, } 3 \\
\text { sessions/week for the whole school year } \\
\text {-Study (2): } \\
\text { Musical training including musical games on rhythm } \\
\text { and timing skills, group singing, understanding } \\
\text { melodies, memory skills, and sequencing skills, } \\
\text { given in } 3 \text { sessions/week, each in } 20 \text { min for } 15 \\
\text { weeks }\end{array}$ \\
\hline
\end{tabular}


Table 3 Results of the included studies

1. Riberio and 2. Habib et al. Santos, 20172016 [11] [12]
3.

Flaugnacco et al., 2015

[13]

\begin{tabular}{l}
\hline Reading \\
Phonological \\
awareness
\end{tabular}

Spelling

Writing

$\begin{array}{ll}\text { Arithmetic } & \text {-Both EA and } \\ & \text { LA: significant } \\ \text { improvement } & \text { in CB, DN, MC, } \\ & \text { RN, CE, and PS } \\ & \text {-Only LA: } \\ \text { increased } \\ \text { scores in PN } \\ \text {-Only EA: } \\ \text { Increased } \\ \text { scores in CD } \\ \text { and WC }\end{array}$

Significant

improvement

-Study (1): identification and discrimination, strong improvement in syllabic duration -Study (2):

Higher than before in identification and discrimination, significant improvement in phonological tasks

\section{Greater} in reading Better

.

-Music group:

Normalization in

improvement

pseudowords

-Music group: performance in phonemic blending task

4. Skeja,

2014 [14]

5. Cogo-Moreira et al., 2013 [15]

6. Register

et al., 2007

7. Overy, 2003

[16]

-By ITT:

Non-significant in nonword accuracy, marginally significant in word accuracy, no observed improvement in text accuracy

-By CACE:

Significant in word accuracy and text accuracy

-Reading

disability

class:

Significant in

WD, WK,

and $\mathrm{RC}$

-Control

class:

Significant in

WD and WK

made gains

not

significantly

in $\mathrm{RC}$

-Treatment

class:

As in control

class

-By ITT:

No observed

improvement

-By CACE:

Significant

-Study (1):

Non-significant in no risk group, significant in mild risk group, and strong risk group

-Study (2):

Significant
-Study (1): improvement in all 3 groups -Study (2): Significant positive effect
Cognitive abilities
-Study (2):

Significant improvement in letter sequence comparison, no change in contour discrimination

$\begin{array}{ll}\text {-Control } & \text { Significant } \\ \text { (painting) } & \text { difference } \\ \text { group: } & \text { between }\end{array}$

-By ITT and CACE: Significant 
Table 3 Results of the included studies (Continued)

\begin{tabular}{|c|c|c|c|c|}
\hline & $\begin{array}{l}\text { 1. Riberio and } \\
\text { Santos, } 2017 \\
\text { [12] }\end{array}$ & $\begin{array}{l}\text { 2. Habib et al., } \\
2016 \text { [11] }\end{array}$ & $\begin{array}{l}3 . \\
\text { Flaugnacco } \\
\text { et al., } 2015 \\
\text { [13] }\end{array}$ & $\begin{array}{l}\text { 4. Skeja, } \\
2014[14]\end{array}$ \\
\hline & & & $\begin{array}{l}\text { Greater } \\
\text { improvement } \\
\text { in visuo- } \\
\text { spatial } \\
\text { reasoning }\end{array}$ & $\begin{array}{l}\text { experimental } \\
\text { group and } \\
\text { control group }\end{array}$ \\
\hline $\begin{array}{l}\text { Auditory } \\
\text { attention }\end{array}$ & & $\begin{array}{l}\text {-Study (2): } \\
\text { Significant } \\
\text { improvement }\end{array}$ & $\begin{array}{l}\text {-Music group: } \\
\text { Larger effect }\end{array}$ & \\
\hline
\end{tabular}

Rapid

$E A$ expected achievement, $L A$ low achievement, $C D$ counting dots, $C B$ counting backwards, $D N$ dictation of numbers, $M C$ mental calculation, $R N$ reading numbers, $P N$ positioning numbers, $O C$ oral comparison, $C E$ contextual estimation, $P S$ problem solving, Wc written comparison.

\section{Discussion}

As of late, it is broadly accepted that music assumes a significant part in learning incapacities. There is an agreement that music learning, music reading, as well as music practice, upgrade scholarly accomplishment, particularly reading and math [18].

The current research aimed to review papers that studied the therapeutic effect of music on children with learning disabilities. After electronic searching on
Science Direct and PubMed databases with our search strategy, two reviewer authors scanned all the yielded papers regarding our inclusion criteria, and only seven studies were matching our inclusion criteria. Finally, the two reviewer authors extracted and analyzed data for each included paper.

The included studies in this systematic review were intervention studies that used different groups of cases (learning disabled, dyslexic or with mathematical

Table 4 Risk of bias summary

\begin{tabular}{|c|c|c|c|c|c|c|}
\hline Authors & $\begin{array}{l}\text { Selection bias } \\
\text { (random sequence } \\
\text { generation) }\end{array}$ & $\begin{array}{l}\text { Selection bias } \\
\text { (allocation } \\
\text { concealment) }\end{array}$ & $\begin{array}{l}\text { Performance bias } \\
\text { (blinding of participants } \\
\text { and personnel) }\end{array}$ & $\begin{array}{l}\text { Detection bias } \\
\text { (blinding of } \\
\text { outcome } \\
\text { assessment) }\end{array}$ & $\begin{array}{l}\text { Attrition bias } \\
\text { (incomplete } \\
\text { outcome data) }\end{array}$ & $\begin{array}{l}\text { Reporting bias } \\
\text { (selective } \\
\text { reporting) }\end{array}$ \\
\hline $\begin{array}{l}\text { 1. Riberio } \\
\text { and Santos, } \\
2017[12]\end{array}$ & 0 & - & + & + & - & - \\
\hline $\begin{array}{l}\text { 2. Habib } \\
\text { et al.,2016 } \\
{[11]}\end{array}$ & + & + & + & + & + & + \\
\hline $\begin{array}{l}3 . \\
\text { Flaugnacco } \\
\text { et al., } 2015 \\
\text { [13] }\end{array}$ & + & + & + & + & + & + \\
\hline $\begin{array}{l}\text { 4. Skeja, } \\
2014[14]\end{array}$ & 0 & 0 & 0 & + & + & + \\
\hline $\begin{array}{l}\text { 5. Cogo- } \\
\text { Moreira } \\
\text { et al., } 2013 \\
{[15]}\end{array}$ & + & + & + & + & + & + \\
\hline $\begin{array}{l}\text { 6. Register } \\
\text { et al., } 2007 \\
{[16]}\end{array}$ & - & + & + & + & + & + \\
\hline $\begin{array}{l}\text { 7. Overy, } \\
2003 \text { [17] }\end{array}$ & - & - & + & + & + & + \\
\hline
\end{tabular}

+ low risk, - high risk, 0 unclear risk of bias 
problems children) which received the music therapy versus different control groups (normal or dyslexic) receiving normal reading program, cognitive or placebo therapy, also they applied different methods and programs of music therapy. Most of the included studies reported that music therapy is a useful aiding factor in rehabilitation therapy of reading and phonological awareness disorders, however little evidence for positive effectiveness regarding spelling, arithmetic, writing, cognitive abilities, working memory, auditory attention, and rapid auditory processing.

In this systematic review, we included all clinical trials whether randomized or not, controlled or not with any sample size as cases of learning disabilities had a wide variation in the results of their assessment, so it is difficult to take unique groups of children with the same results of assessment tests. In addition to that, we intended to collect as much evidence as we can. We excluded systematic reviews and meta-analyses as they are considered as secondary sources and our research-based on original research articles. These criteria for the included study design are matched with the systematic review of Rolka and Silverman [19]. On the other hand, Cogo-Moreira et al. systematic review [20] restricted inclusion criteria for only randomized controlled trials, for that the last one collected zero included studies.

In our study, data was accepted from any country without limitation as long as it fulfills our inclusion criteria. That was done because it was difficult to take researches from the Middle East and Arabic-speaking countries due to the lack of enough researches made in the Arabic language. So, to have enough results we had to take different researches from different countries either developed or developing. This strategy was the same in many studies $[7,8,11-19,21,22]$.

We required studies published only in the English language as the English language is the main and dominant language for publishing research worldwide following Rolka and Silverman [19]. Certainly, the research in other languages could contribute to the knowledge base of music therapy role with learning disabilities. Besides, it would be better to find research in the Arabic language where Arabic tests of learning disabilities are applied uniformly, but no papers fulfilling the inclusion criteria were found.

Regarding the included age of participants, it ranged from 5 to 12 years that reversed to the brain plasticity theory which says that earlier intervention has a better prognosis than intervention received in later life [21]. This selection of definite age range led to the limited number of our included studies (7 studies), but if we had taken all ages for participants (children and adults), it could lead to mixing and confusion of results. Unlike our study, Rolka and Silverman [19] which included the age range of participants from 6 to 36 years, also took all studies with dyslexia and music in their titles whatever their study design, so it included a bigger number of studies (23 studies). It was found that 18 studies included only children and 5 studies included adults. So, the difference in the number of included studies between the systematic review of Rolka and Silverman [19] and ours didn't come from the included age.

Concerning the publishing date of the included papers, it was set to be from 1999 to 2020 to obtain recent results and not repeat the work of the previous systematic reviews. That could be a contributing factor in the limitation of the number of our results, unlike Rolka and Silverman's study [19] which did not limit the publication date so it gathered increased but not updated results.

Regarding the tests used for IQ evaluation of the subjects of the included studies, We included researches assessed their participants with different IQ tests like the Wechsler Intelligence Scale for Children third edition (WISC III), the Wechsler Intelligence Scale for Children fourth edition (WISC IV), the Cognitive Assessment System (CAS) and the Raven s Colored Progressive Matrices (RCPM). This could be explained as our studies came from different countries where different formal IQ tests are applied. This may be considered acceptable as long as the tests used are standardized ones. This was the same as the systematic review of Rolka and Silverman [19], as well as meta-analyses of Standley [21], Butzlaff [7], and Standley [22], and all of them accepted different IQ tests which did not affect their results.

Also, we accepted any standardized or unstandardized tests and $/$ or batteries for pre/post music training evaluation of learning disabilities this was because of the limited number of papers dealt with the use of music therapy in learning disabilities. Certainly, we were hoping to find studies with unified standardized tests to ease the comparison between the results and made a certainty of results significance but as the research came from different countries (with different languages) that apply their tests and it was very difficult to find studies that unify these tests, as well as no previous systematic review with a similar topic, could collect studies with unifying tests. Also, Rolka and Silverman [19], included studies that used different tests for evaluation of reading skills and this point did not affect the result.

Indeed, we required participants to be children with learning disabilities diagnosis (dyslexics, arithmetic problems, or writing problems), this is based on the metaanalysis of Standley [22] which stated that music functioned as a reinforcer and gave greater benefit to academic fields (as reading, writing, and mathematics) than health. As another reason, it was an advantage to collect variable outcomes serving one final aim which gave this study much value as the first systematic review to gather 
these outcomes together. Like us, Standley [22] collected 98 studies and evaluated 208 variables without dispersion in his results. Unlike us, systematic reviews of Cogo-Moreira et al. [20], and Rolka and Silverman [19], as well as the meta-analysis of Butzlaff [7], limited their collected studies to be focusing on music therapy in dyslexic children only.

Besides, our systematic review gathered studies that applied the different programs of music therapy whether alone or combined with cognitive therapy, this is based on the theory stated by Standley [21] who made a metaanalysis to study the effect of different music interventions on reading skills in children and collected 30 studies and the results showed that the music interventions were equally effective for durations ranging from less than 4 weeks to those occurred thorough the whole year, so he declared that all schedules of music interventions can function equally well to improve reading that is why we accepted different music therapy programs. As another explanation, we found that all involved programs in our systematic review were based on a common approach of music therapy such as Suzuki, Dalcroze, Kodaly, and Orff methods, and all of the included studies used live music. In agreement with us, the systematic review of Rolka and Silverma $\mathrm{n}[19]$ as well as metaanalyses of Standley [21], Butzlaff [7], and Standley [22], all of them included the different programs of music therapy without affecting their results negatively.

Accordingly, our systematic review reported the impact of music therapy on the following outcomes: reading skills, phonological awareness, spelling, writing skills, arithmetic cognition, working memory, auditory attention, and rapid auditory processing.

Regarding reading and phonological awareness, this systematic review revealed that Register et al. [16], Cogo-Moreira [15], Flaugnacco et al. [13], and Habib et al. [11] concluded that music has a significant role in the improvement of reading and phonological awareness. There are several explanations about why music can have an effective additional role to help dyslexic children. Music training is a multisensory activity that makes an effective mode of learning for dyslexics. Music enhances auditory and rhythmic processing skills as they are brain functions that can be generalized to literacy skills [23]. Also, the main mechanism of improving reading skills is the improvement of weakness in phonological awareness skills. Our results regarding reading and phonological awareness improvement are in agreement with Standley [22], Butzlaff [7], and Standley [21]. Regarding non-significant improvement in reading reported by Overy [17], it may be due to comparing the non-music trained period with the music trained period of the same dyslexic group without the use of a control group. Besides, we suggest that music training was short; not long enough to induce adequate results as compared with other studies.

Our systematic review showed that Overy [17], reported significant improvement of spelling in children with a mild and strong risk of dyslexia. It has been found that spelling improvement precedes reading improvement in dyslexic children in other intervention studies. Also, there is an agreement that phonological improvements more likely lead to spelling improvement because spelling is phoneme-to-grapheme skill while reading is grapheme to phoneme skill that can be based on visual recognition and context. Moreover, it has been suggested that there is a strong relationship between spelling and phonological awareness in the early stages of learning. This result agrees with the results reported in Martin [24].

Regarding writing, we reported that Habib et al. [11] showed improvement in letter sequence comparison, the improvement was significant for speed but marginally significant for accuracy. It was found that music could have a therapeutic effect on enhancing classroom attending behaviors as well as working memory which could lead to some improvements in writing skills in learning disabled children. This is in agreement with Vandermosten et al .[25]

Concerning arithmetic problems, Riberio and Santos [12] and Cogo-Moreira et al. [15] reported significant improvement with music therapy. Researchers suggest that music can increase higher brain functions required for mathematics, chess, and engineering. Many studies showed associations between music lessons and academic performance such as mathematics, reading, and spelling. The improvement in math scores after music training may be due to the near and far transfer effect as music training produces an increase in children s auditory skills (as auditory discrimination), verbal short-term memory, executive functions, and working memory. Like us, Willis [26] found that there is a significant connection between music education and student achievement in math, for those students who received music education at school.

Concerning cognitive abilities, Skeja [14] showed significant improvement in cognitive abilities in children with learning disabilities who received both music and cognitive therapies. It was found that musical training could be used to produce fast and permanent changes in cognitive abilities and an improvement in visuospatial ability. It could also be argued that musical training was associated with greater performance on tests of reasoning, working memory, processing speed, and numeracy ability In agreement with this systematic review, Esteki [27] tested cognitive abilities pre and post 16 sessions of music training in 13 girls (7-9 years), the results demonstrated increased scores in verbal, non-verbal, and general IQ and numerical scores. 
Additionally, we detailed that Flaugnacco et al. [13] indicated improvement in working memory. It is recommended that youngsters getting music training advantage explicitly in those parts of cognitive functioning that are emphatically identified with hear-able data handling.

Like our outcomes, Roden et al. [28], made a clinical preliminary to consider the impact of music training on working memory and tested the central executive, the phonological loop, and the visuospatial sketchpad components of Baddeley's working memory model, at long last they revealed a critical improvement.

For auditory attention, Flaugnacco et al. [13], and Habib et al. [11] reported significant improvement with music therapy, in addition to that, rapid auditory processing improved significantly [17]. This could be explained by the hypothesis mentioned in Tallal and Gaab study [29] which researched the relationship between auditory attention, rapid auditory processing, language skills, and reading abilities, then hypothesized that music training could influence the attention and rapid auditory processing through changing the underlying functional anatomy, finally lead to language skills improvement and consequently reading improvement. This was in following Esteki [27].

\section{Conclusion}

The evidence regarding the role and efficacy of music therapy in reading and phonological awareness was much more if compared to the role and efficacy of music therapy in spelling, arithmetic, writing, cognitive abilities, working memory, auditory attention, and rapid auditory processing. Music therapy (with or without cognitive therapy) has an important and augmenting role in improving reading skills and phonological awareness problems in dyslexic children but does not replace the current methods of rehabilitation. There is little evidence found that music therapy (with or without cognitive therapy) is an effective aiding factor in rehabilitation therapy regarding spelling, arithmetic, writing, cognitive abilities, working memory, auditory attention, and rapid auditory processing in learning disabled children.

A music therapy program should be tailored by a welltrained music therapist under the supervision of the phoniatrician in a specific adequate manner to improve areas of deficits in children with learning disabilities.

More researches, in Arabic-speaking countries, are needed before establishing the music therapy program as a formal rehabilitative method in combination with the well-known rehabilitation methods of learning disabilities.

From this systematic review, the following items are recommended:
1. Further researches must be done in the form of randomized clinical trials with a control group (receiving a placebo therapy) and on a larger sample size.

2. Establishing a worldwide protocol using standardized protocols of assessment in order to facilitate comparisons between different outcomes.

3. Encouraging researches in Arabic-speaking countries.

4. Using neuroimaging and electrophysiological examination in addition to literacy tests to determine the neurological changes with music therapy.

\section{Abbreviations}

BIA: Bioelectrical impedance analysis; CACE: Complier-average aausal effect; CAS: Cognitive assessment system; CMT: Cognitive music training; DEST: Dyslexia Early Screening Test; DST: Dyslexia Screening Test; EA: Expected achievement; GMRT: Gates-MacGinitie Reading Test; IQ: Intelligence quotient; ITT: Intention to treat; L.D: Learning disabilities; LA: Low achievement; MADST: Modified Arabic Dyslexia Screening Test; MC: Mental calculation; MT: Music therapy; NIMT: Non-instrumental musical training; P.A: Phonological awareness; PAT: Phonological Awareness Test; PN: Positioning numbers; PRISMA: Preferred Reporting Items for Systematic Reviews and Meta-Analyses; SLD: Specific learning disabilities; WC: Written comparison; WORD: Wechsler Objective Reading Dimensions

Acknowledgements

Not applicable.

Authors' contributions

Assistant Prof. M E and Assistant Prof. A N have an equal role in the design Lecturer of Phoniatrics Dr. S M and Phoniatrics Resident Dr. F M have an equal role in the design, work, and manuscript writing. All authors have read and approved the manuscript for publication.

\section{Funding}

This research received no specific grant from any funding agency in the public, commercial, or not-for-profit sectors.

Availability of data and materials

All data generated or analyzed during this study are included in this published article.

\section{Declarations}

Ethics approval and consent to participate

A systematic review study was carried out following the approval of the Research Ethical Committee of Faculty of Medicine, Phoniatric Unit, Tanta University (approval code: 32980/03/19), there were no patients in the study.

Consent for publication

Not applicable.

Competing interests

The authors declare that they have no competing interests.

\section{Author details}

'Unit of Phoniatrics, Otorhinolaryngology Department, Faculty of Medicine, Tanta University, Tanta, Egypt. ${ }^{2}$ Unit of Phoniatrics, Otorhinolaryngology Department, Faculty of Medicine, Ain-Shams University, Cairo, Egypt. 
Received: 26 November 2020 Accepted: 18 March 2021

Published online: 14 April 2021

\section{References}

1. El-Sady SR, El-Shoubary AM, Hafez GN, Abo-Hasseba AM (2011) Translated, modified, and standardized Preschool Language Scale [Unpublished Thesis], 4th edn. Ain Shams Medical School, Cairo

2. Overy K (2000) Dyslexia, temporal Processing, and music: the potential of music as an early learning aid for dyslexic children. Psychol Music 28(2):218229. https://doi.org/10.1177/0305735600282010

3. Weiss AH, Granot RY, Ahissar M (2014) The enigma of dyslexic musicians, Neuropsychologia 54:28-40. https://doi.org/10.1016/j.neuropsychologia.2 013.12 .009

4. Hyde K, Lerch J, Norton A, Forgeard M, Winner E, Evans A, Schlaug G (2009) The effects of musical training on structural brain development. Ann N Y Acad Sci 1169(1):182-186. https://doi.org/10.1111/j.1749-6632.2009.04852.x

5. Forgeard M, Schlaug G, Norton A, Rosam C, lyengar U, Winner E (2008) The relation between music and phonological processing in normal-reading children and children with dyslexia. Music Percept 4:383-390

6. Schellenberg EG (2006) Long-term positive associations between music lessons and IQ. J Educ Psychol 98(2):457-468. https://doi.org/10.1037/00220663.98.2.457

7. Butzlaff R (2000) Can music be used to teach reading? J Aesthetic Educ 34(3):167-178. https://doi.org/10.2307/3333642

8. Vandermosten M, Boets B, Poelmans H, Sunaert S, Wouters J, Ghesquiere P (2012) A tractography study in dyslexia: neuroanatomic correlates of orthographic, phonological and speech processing. Brain 135(3):935-948. https://doi.org/10.1093/brain/awr363

9. Nicholson, D (1972) Music as an aid to learning. Doctoral dissertation, New York University, School of Education

10. Copans-Astrand D (2000) The effect of rhythm-based Orff-Schulwerk music therapy on the reading skills of students in varying exceptionalities classes. Doctoral dissertation. Florida State University

11. Habib M, Lardy C, Desiles T, Commeiras C, Chobert J, Besson M (2016) Music and dyslexia: a new musical training method to improve reading and related disorders. Front Psychol 7(1):26

12. Ribeiro FS, Santos FH (2017) Enhancement of numeric cognition in children with low achievement in mathematic after a non-instrumental musical training. Res Dev Disabil 62:26-39. https://doi.org/10.1016/j.ridd.2016.11.008

13. Flaugnacco E, Lopez L, Terribili C, Montico M, Zoia S, Schön D (2015) Music training increases phonological awareness and reading skills in developmental dyslexia: a randomized control trial. PLoS One 10(9): e0138715. https://doi.org/10.1371/journal.pone.0138715

14. Skeja $E$ (2014) The impact of cognitive intervention program and music therapy in learning disabilities. Procedia Soc Behav Sci 159:605-609. https:// doi.org/10.1016/j.sbspro.2014.12.433

15. Cogo-Moreira H, de Avila CRB, Ploubidis GB, de Jesus Mari J (2013) Effectiveness of music education for the improvement of reading skills and academic achievement in young poor readers: a pragmatic clusterrandomized, controlled clinical trial. PLoS One 8(3):e59984. https://doi.org/1 0.1371/journal.pone.0059984

16. Register D, Darrow AA, Swedberg O, Standley J (2007) The use of music to enhance reading skills of second grade students and students with reading disabilities. J Music Ther 44(1):23-37. https://doi.org/10.1093/jmt/44.1.23

17. Overy K (2003) Dyslexia and music: From timing deficits to musical intervention. Ann N Y Acad Sci 999(1):497-505. https://doi.org/10.1196/anna Is. 1284.060

18. Darrow AA, Cassidy JW, Flowers PJ, Register D, Sims W, Standley JM, Menard E, Swedberg $O$ (2009) Enhancing literacy in the second grade: Five related studies using the register music/ reading curriculum. Appl Res Music Educ 27(2):12-26. https://doi.org/10.1177/8755123308330044

19. Rolka EJ, Silverman MJ (2015) A systematic review of music and dyslexia. Arts Psychother 46:24-32. https://doi.org/10.1016/j.aip.2015.09.002

20. Cogo-Moreira H, Andriolo RB, Yazigi L, Ploubidis GB, de Ávila CRB, Mari JJ (2012) Music education for improving reading skills in children and adolescents with dyslexia. Cochrane Database of Systematic Reviews 1(8)

21. Standley JM (2008) Does music instruction help children learn to read? Evidence of a meta-analysis. Appl Res Music Educ 27(1):17-32

22. Standley JM (1996) A meta-analysis on the effects of music as reinforcement for education/ therapy objectives. J Res Music Educ 44(2):105-133. https:// doi.org/10.2307/3345665
23. Flaugnacco E, Lopez L, Terribili C, Zoia S, Buda S, Tilli S, Monasta L, Montico M, Sila A, Ronfani L, Schön D (2014) Rhythm perception and production predict reading abilities in developmental dyslexia. Front Hum Neurosci 8(2):392

24. Martin M (1983) Success! Teaching spelling with music. Acad Ther 18(4): 505-507. https://doi.org/10.1177/105345128301800418

25. Vandermosten $M$, Boets $B$, Wouters J, Ghesquière $P$ (2012) A qualitative and quantitative review of diffusion tensor imaging studies in reading and dyslexia. Neurosci Biobehav Rev 36(6):1532-1552. https://doi.org/10.1016/j. neubiorev.2012.04.002

26. Willis CG (2016) Impact of music education on mathematics achievement scores among middle school students. Res Dev Disabil 36:741-770

27. Esteki, M (2013) Effectiveness of" Music Training" on reorganization of brain and poor intellectual abilities in female students with dyscalculia (7-9 years old). Global Journal of Arts Education 3(2):306-310

28. Roden I, Grube D, Bongard S, Kreutz G (2014) Does music training enhance working memory performance? Findings from a quasi-experimental longitudinal study. Psychol Music 42(2):284-298. https://doi.org/10.1177/03 05735612471239

29. Tallal P, Gaab N (2006) Dynamic auditory processing, musical experience, and language development. Trends Neurosci 29(7):382-390. https://doi. org/10.1016/j.tins.2006.06.003

\section{Publisher's Note}

Springer Nature remains neutral with regard to jurisdictional claims in published maps and institutional affiliations.

\section{Submit your manuscript to a SpringerOpen ${ }^{\circ}$ journal and benefit from:}

- Convenient online submission

- Rigorous peer review

- Open access: articles freely available online

High visibility within the field

- Retaining the copyright to your article

Submit your next manuscript at $>$ springeropen.com 